4116

\title{
防振コムを用いた動吸振器の特性*
}

\author{
尾崎晃一*1, 橋 本 和 浩*2, 神 保 泰 雄*1
}

\section{Characteristics of Dynamic Absorber Using Rubber Vibration Isolator}

\author{
Kouichi OZAKI, Kazuhiro HASHIMOTO and Yasuo JIMBO
}

\begin{abstract}
Elastic suspension systems are widely used for vibration reduction purpose. When disturbance vibrations contain undesirable frequencies, resonances may occur and the movements of the suspensions become harmful. In order to avoid the large resonances, dynamic absorbers are used. Then the systems assume two degrees of freedom. In this paper, characteristics of these systems are treated. The spring elements for both the main suspension systems and the dynamic absorbers are assumed to be rubbers which have complex spring constants. When the main suspension systems have no damping, the fixed point theory can be used and the optimum tuning condition and loss factor are obtained. When the main systems have dampings, optimum values are derived by introducing correction factors. Vibration transmissibilities are measured experimentally. The results show good agreement with calculated ones. It is concluded that the complex spring models can be applied for calculating vibration transmissibilities of dynamic absorbers using rubber vibration isolators.
\end{abstract}

Key Words: Vibration Isolation, Damping Material, Vibration Control Device, Dynamic Absorber, Rubber Vibration Isolator, Complex Stiffness, Loss Factor

1. 緒

振動絶縁，振動吸収材料として広く用いられている 防振ゴムは防振, 除振, 制振そして免震装置の一部と して広範囲に利用されている。しかし，防振ゴムと質 量で構築された 1 自由度振動系では共振周波数域で振 動伝達率がかなり大きくなる。この振動伝達率を低隇 するために, 小さな質量と防振コムで構築された動吸 振器を主振動系に設置した 2 自由度振動系の振動解析 と実験を試みた。 2 自由度振動系のばねについては複 素ばねを適用し, 定点理論の解析手法 ${ }^{(1)(2)} に よ り$ 最適 同調条件, 最適損失係数などを導出する ${ }^{(3)(4)}$.

積載質量と防振ゴムで作られた振動系に動吸振器を 設置した装置を試作し振動伝達率測定実験を実施し， 解析結果と比較検討を行う(5).

\section{2. 定点理論による解析}

$2 \cdot 1$ 振峌伝逵率図 1 は動吸振器が設置された 2 自由度振動系の等価モデルでばね要素には防振ゴム

* 原稿受付 平成 6 年 3 月 25 日.

*1 正員, 東海大学工学部 ( $259-12$ 平塚市北金目 1117).

*2 学生員, 東海大学大学院 [現：月島機械(株)（西104 東京都中 央区佃 2-17-15)].
を用いている。通常の外乱振動は主振動系 (以後, 主系 と呼ぶ)の防振ゴで防ぎ主系の共振近傍に近い特殊 な外乱が来たときに動吸振器で共振振幅をおさえよう とするものである. 主系, 動吸振器系の防振ゴムのば ね定数を次式に示すように複素数でモデル化する。

$$
\begin{aligned}
k^{*} & =k^{\prime}+j k^{\prime \prime} \\
& =k^{\prime}(1+j \varepsilon)
\end{aligned}
$$

式 (1)の左辺の $k^{*}$ は複素ばね定数と呼ばれ, 右辺の 第 1 項は動的ば柱数, 第 2 項は動的損失定数であ る. 式 (2)の $\varepsilon=k^{\prime \prime} / k^{\prime}$ は損失係数(ロスファク夕)であ り，防振ゴムの減衰の程度を示す大事な係数である.j は虚数単位である. 複素ばね定数 $k_{1}^{*}, k_{2}^{*}$ はともに周 波数および振幅依存性のないものとする．ゴムのばね

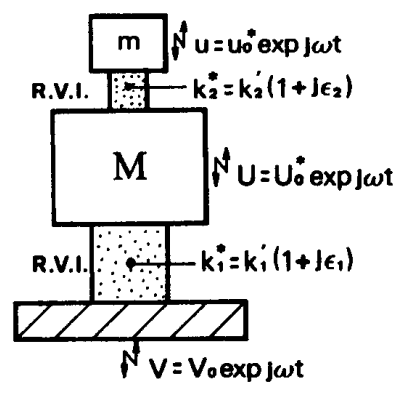

図 1 動吸振器が付加された振動系の等価モデル 
定数は温度に依存することが知られているがここでは 温度の影響は考慮しないことにする．主系の基礎を強 制変位振動 $V$ で加振したときの積載質量 $M$ の装位 振動を $U$, 動吸振器の質量 $m$ の変位振動を $u$ とおけ ば, 運動方程式は次式となる。

$$
\begin{aligned}
& M \ddot{U}=k_{1}^{*}(V-U)-k_{2}^{*}(U-u) \\
& m \ddot{u}=k_{2}^{*}(U-u)
\end{aligned}
$$

上式において，個々の振動変位を次式のようにおき，

$$
V=V_{0} e^{j \omega t}, U=U_{0}^{*} e^{j \omega t}, u=u_{0}^{*} e^{j \omega t}
$$

主系の振動伝達率を求めると次式が得られる.

$$
T=\left|\frac{U_{0}^{*}}{V_{0}}\right|=\sqrt{\frac{R_{u}^{2}+I_{u}^{2}}{R_{d}^{2}+I_{d}^{2}}}
$$

ここて

$$
\begin{aligned}
& R_{u}=1-\varepsilon_{1} \varepsilon_{2}-(\mu / \alpha)\left(\omega / \omega_{n}\right)^{2} \\
& I_{u}=\varepsilon_{1}+\varepsilon_{2}-\varepsilon_{1}(\mu / \alpha)\left(\omega / \omega_{n}\right)^{2} \\
& R_{d}=1-\varepsilon_{1} \varepsilon_{2}-(1+\mu+\mu / \alpha)\left(\omega / \omega_{n}\right)^{2} \\
& \quad+(\mu / \alpha)\left(\omega / \omega_{n}\right)^{4} \\
& I_{d}=\varepsilon_{1}+\varepsilon_{2}-\left\{\varepsilon_{1}(\mu / \alpha)+\varepsilon_{2}(1+\mu)\right\} \\
& \quad \times\left(\omega / \omega_{n}\right)^{2} \\
& \mu=m / M, \alpha=k_{2}^{\prime} / k_{1}^{\prime}, \omega_{n}=\sqrt{k_{1}^{\prime} / M} \cdots
\end{aligned}
$$

である。

$2 \cdot 2$ 主系に損失がない場合 図 2 は主系の損失 係数 $\varepsilon_{1}$ を零, $\mu$ と $\alpha$ を 0.1 とおき $\varepsilon_{2}$ の值を $0,0.2$ および 0.4 と変化させたときの振動伝達率線図であ る. 主系の損失係数が零であるならば定点 $\mathrm{P}, \mathrm{Q}$ が存 在する。そこで, 式( 5 )，（6）にばね-隇衰器系の動吸 振器で用いられている $\mathrm{P}, \mathrm{Q}$ 定点理論(1)(2) を適用する ことにより最適同調条件, 最適損失係数等を導出てき る.はじめに $\varepsilon_{2}=0$ と $\varepsilon_{2}=\infty$ 二つの振動伝達率曲線 の交点は損失係数 $\varepsilon_{2}$ の値に無関係に定まることから 定点 $\mathrm{P}, \mathrm{Q}$ を求め, 次にこの定点 $\mathrm{P}, \mathrm{Q}$ の高さを等し くする条件，すなわち最適同調条件が導かれる。そし て最適同調条件を用いて定点 $\mathrm{P}, \mathrm{Q}$ の高さを極大にす る条件は振動伝達率 $T$ の両辺を二乗して $\omega^{2}$ で偏微 分したものを零とおけば $\varepsilon_{2}$ に関する四次代数方程式

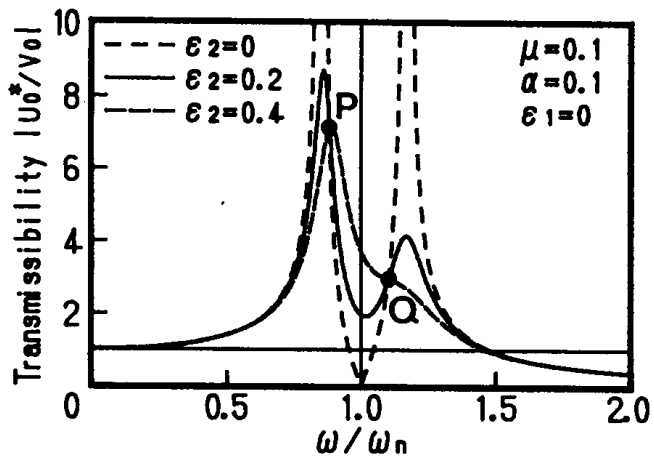

図 2 主系に損失係数をもたない振動伝達率線図
が導かれ，これを解くと最適損失係数が算出できる。 これらの計算については省略し結果のみを書くと次式 のようになる。ここで, 著者らは最適同調条件は従来 用いている角振動数比のパラメータよりも，むしろば ね定数比 $\alpha$ に注目した。 それは後者のパラメータのほ うが防振コムを用いた動吸振器の最適設計ならびに制 振効果を論じるには好都合であるからである。

〔最適同調条件〕

$$
\begin{aligned}
& \alpha_{\mathrm{opt}}=\frac{\mu}{(1+\mu)^{2}} \\
& \frac{\omega_{P}}{\omega_{n}}, \frac{\omega_{Q}}{\omega_{n}}=\sqrt{\frac{1}{1+\mu}\left(1 \mp \sqrt{\frac{\mu}{2+\mu}}\right)} \\
& T_{P}=T_{Q}=\sqrt{\frac{2+\mu}{\mu}}
\end{aligned}
$$

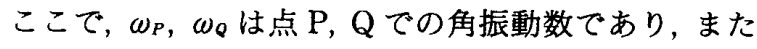
$T_{P}, T_{Q}$ は点 $\mathrm{P}, \mathrm{Q} て ゙ の$ 振動伝達率である.

〔最適損失係数〕

$$
\varepsilon_{2 P}, \varepsilon_{2 Q}=\sqrt{\frac{\mu}{2+\mu}[3+2 \mu \mp 2 \sqrt{\mu(2+\mu)}]}
$$

動吸振器の定点理論では上式の複号のどちらの值をと っても現実的な調整においては大差を生じないのでこ こでは両者の相加平均が最適損失係数を与えると定義 する.したがって,

$$
\begin{aligned}
\varepsilon_{2 \mathrm{opt}} & =\left(\varepsilon_{2 P}+\varepsilon_{2 Q}\right) / 2 \\
& =\sqrt{\frac{\mu}{2(2+\mu)}(3+2 \mu+\sqrt{9+4 \mu})} \\
& \fallingdotseq \sqrt{\frac{\mu}{2+\mu}(3+2 \mu)} \cdots \cdots \cdots \cdots \cdots \cdots \cdots \cdots
\end{aligned}
$$

となる．すなわち防振ゴムを用いた動吸振器の最適同 調条件, 最適損失係数等はばね-減衰器系の動吸振器 と同様に質量比の関数で表すことができる.図 3 はこ れらを $\mu$ れついてグラフ化したもので, 質量比 $\mu$ が 増加すると $\alpha_{\mathrm{opt}}$ と $\varepsilon_{2 \mathrm{opt}}$ はともに増えている，また，図

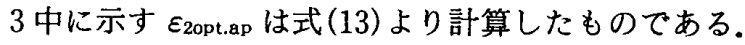
図 4 は主系の損失係数が零の場合で質量比 $\mu$ が, 0.1 , 0.2 およ゙ 0.3 のとの最適調整された振動伝達率線 図である，図 4 中において，横軸 $\omega / \omega_{n}=1$ の左右にあ る振動伝達率の両極大值を比較すると, 右側極大值の ほうが左側のそれよりわずかに大きい。これは式(12) による $\varepsilon_{2}$ の選定の近似性によるものである.

$2 \cdot 3$ 主系に損失がある場合主系に防振ゴムを・ 使う場合防振ゴムには必ず損失があるからこれを考慮 にいれなければならない， $\varepsilon_{1}=0.1$ の場合，式（5)によ り振動伝達率線図を描いたのが図 5 である.図 5 中の 大きな○印の簓所は主系の損失係数が零でないために 定点 $\mathrm{P}, \mathrm{Q}$ が存在していないことを示している.図 6 


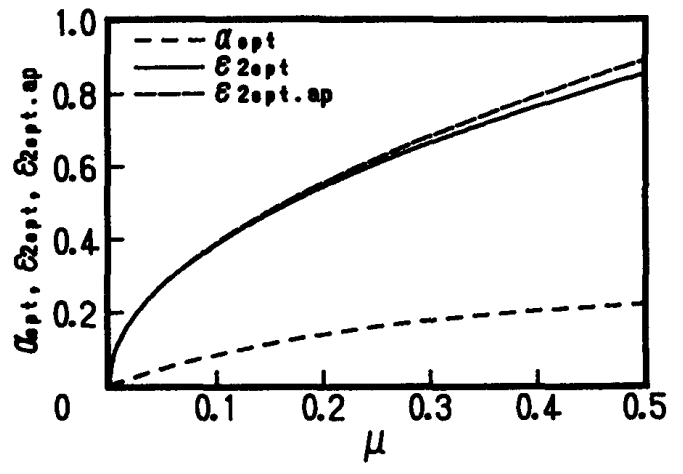

図 3 最適同調条件, 最適損失係数と質量比の関係

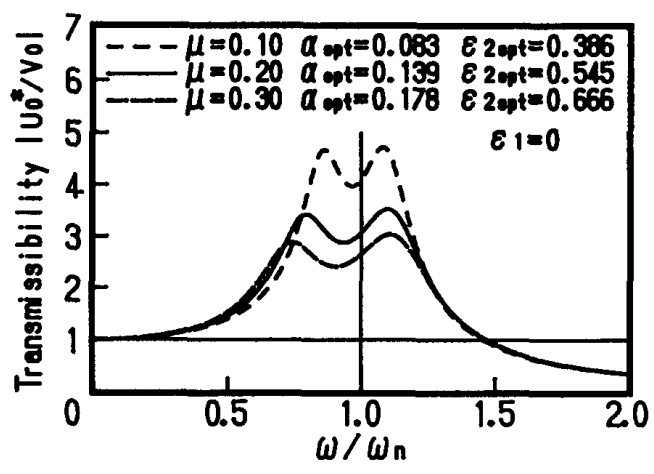

図 4 最適調整された振動伝達率線図

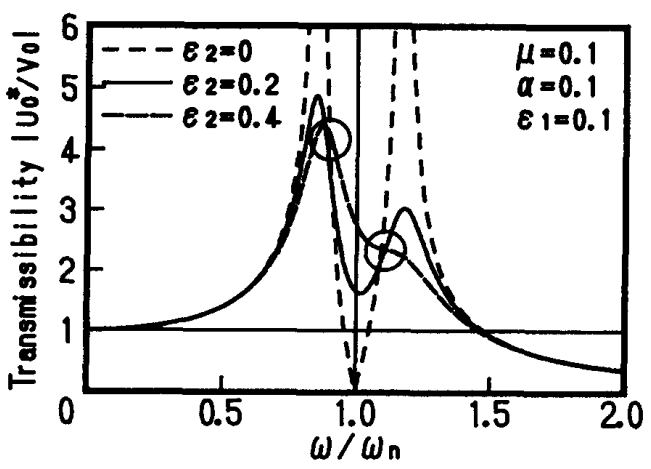

図 5 定点 $P, Q$ が存在しない振動伝達率線図

は主系の防振ゴムの損失係数を $\varepsilon_{1}=0.1$ と仮定し, 式 （8），(12）を適用した場合の振動伝達率線図である. 損失係数が零でない影響のために，両極大值の差はや や大きくなっている. 主系に減衰 (損失係数)が存在す るとき，振動伝達率の両極大值を等しくするような $\alpha$ と $\varepsilon_{2}$ とを解析的に導くことは不可能である. そこで, この解決策として数值シミュレーションを試みた結 果, 減衰がない場合の最適同調条件式 (8)に適当な数 值を乗ずると両極大值が等しくなることを見いだし た。したがって主系に減衰がある防振ゴムを用いた動 吸振器の最適同調条件は次式のような補正をすること で動吸振器の実用的な設計が可能である.

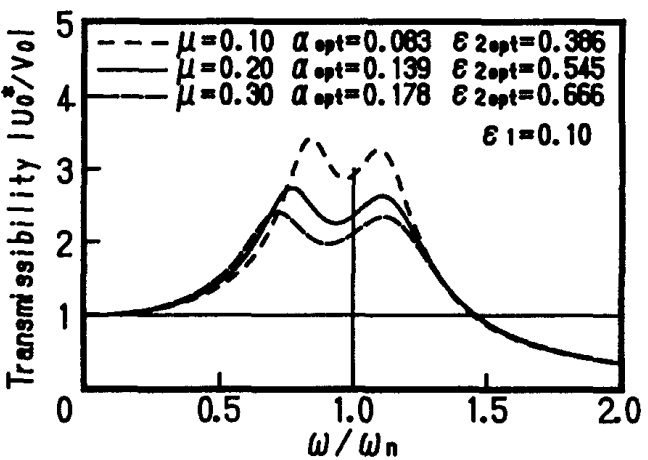

図 $6 \quad \varepsilon_{1}=0.1$ のときの振動层達率線図

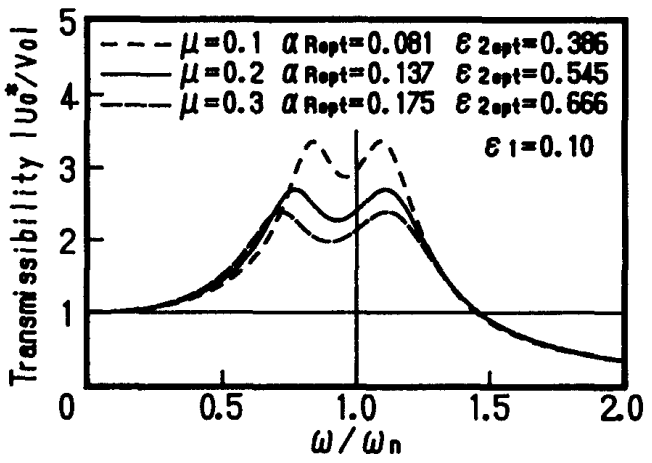

図 7 補正係数を用い最適調整された振動伝達率線図

$$
\alpha_{\mathrm{Ropt}}=\frac{\mu}{(1+\mu)^{2}} \cdot R
$$

ここで, $R$ は両極大值を等しくする補正係数である. 図 7 は式(12)，(14）を用いた主系に損失係数がある場 合の振動伝達率線図を示している.この例では $\mu=0.1$, $0.2,0.3$, の場合 $R=0.984,0.984,0.988$ で 1 よりわずか に小さい値になっている.図 7 は防振ゴムを用いた動 吸振器として十分な最適調整がされていることを示 す。

\section{3.ばね-減表器の勤吸振器との比較}

主系および動吸振器にばねと減衰器を用いる場合は 2 章の損失係数 $\varepsilon_{1}$ と $\varepsilon_{2}$ のところに $c_{1} \omega / k_{1}, c_{2} \omega / k_{2}$ を 入れればよい.したがって最適隇衰比 $\zeta_{2 \mathrm{opt}}$ は次のよう になる。

$$
\begin{aligned}
& \varepsilon_{2 P}, \varepsilon_{2 Q}=2 \zeta_{2 P}, 2 \zeta_{2 Q}\left(\frac{\omega_{P, Q}}{\omega_{d}}\right) \\
& \frac{\omega_{P, Q}}{\omega_{d}}=\sqrt{(1+\mu)\left(1 \mp \sqrt{\frac{\mu}{2+\mu}}\right)} \\
& \omega_{d}=\sqrt{k_{2} / m} \\
& \zeta_{2 \mathrm{opt}}=\frac{1}{4}\left[\varepsilon_{2 P}\left(\frac{\omega_{d}}{\omega_{P}}\right)+\varepsilon_{2 Q}\left(\frac{\omega_{d}}{\omega_{Q}}\right)\right] \\
& \varepsilon_{20 \mathrm{pt}}=\zeta_{2 P}\left(\frac{\omega_{P}}{\omega_{d}}\right)+\zeta_{2 Q}\left(\frac{\omega_{Q}}{\omega_{d}}\right)
\end{aligned}
$$




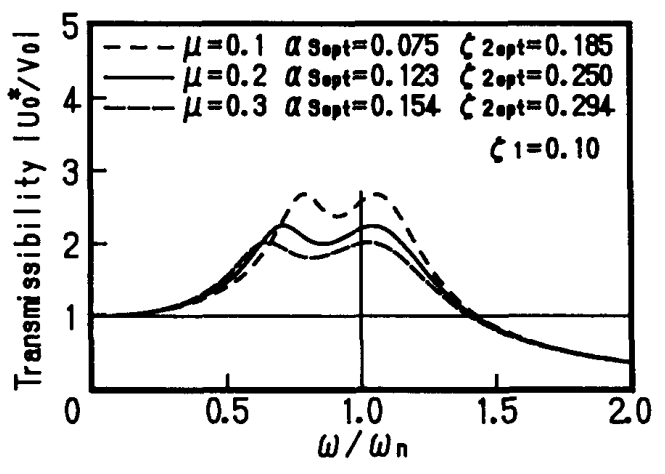

図 8 補正係数を用い最適調整された振動伝達率線図

$$
\frac{\zeta_{2 \mathrm{opt}}}{\varepsilon_{2 \mathrm{ppt}}}=\sqrt{\frac{3(2+\mu)+\sqrt{2(2+\mu)(9+4 \mu)}}{8(1+\mu)[3+2 \mu+\sqrt{9+4 \mu}]}}
$$

そして主系に減衰がある動吸振器の最適同調条件は次 式のように補正すれば実用に適した最適設計が可能で

$$
\alpha_{\text {sopt }}=\frac{\mu}{(1+\mu)^{2}} \cdot S
$$

ある。図 8 は $\zeta_{1}=0.1$ と仮定し, 補正係数 $S$ を用いた ときの最適調整された振動伝達率線図である.この例 では $S=0.908,0.886,0.868$ の值である.

\section{4. 防振ゴムを用いた動吸振器の最適設計}

調整可能な減衰器をもつ動吸振器の設計にあたつて はまず質量比 $\mu$ を決め, 次に定点理論を用いてばねや 減衰の定数を定めるという手法がとられることが多 い。防振ゴムを用いる場合，ばね定数は寸法を調整す ることにより希望の値をとらせることができるが損失 係数 はゴムの種類によって決まる固有な值である ため計算で希望の損失係数を求めてもこれを満たす適 当なゴムが得られるとは限らない。この場合まず用い るゴムを決め, そのゴムの損失係数をカタログや技術 資料，あるいは実測で求めてから $\mu$ とばね定数比 $\alpha$ の最適值を求めるほうが実際的である。

最適な質量比 $\mu$ を選ぶため式(5)を用いていくつ かの損失係数 $\varepsilon_{1}, \varepsilon_{2}$ に対して振動伝達率と質量比との 関係を三次元表示で表したものが図 9，10である， $\mu$ がある值より大きいと共振の山が二つできる，左右の 山の高さは等しくなっていないがこれは $\alpha_{\mathrm{opt}}$ として 式（８）の值を用いたためであり式(14)のように補正す れば等しくすることは可能である。この図 9,10 の例 では $\omega / \omega_{n}=1$ の左側の極大值は $\mu$ が増せば漸次低く なっていき，右側のそれは質量比が小さい範囲で極小 值と極大值(図 9,10 中では表していない)をもち，そ れ以後は漸次低くなっていき，質量比が大きいほど制

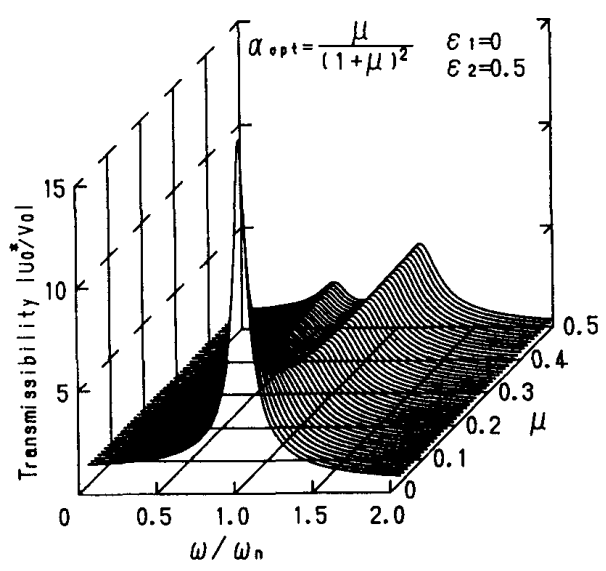

図 9 三次元表示した振動伝達率線図

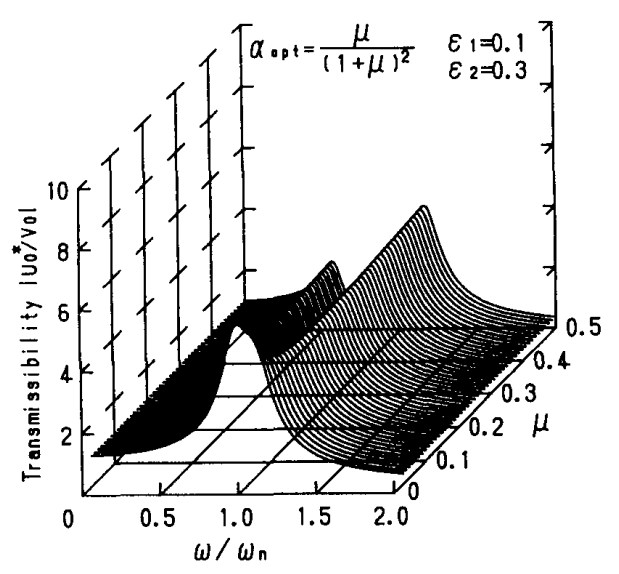

図 10 三次元表示した振動伝達率線図

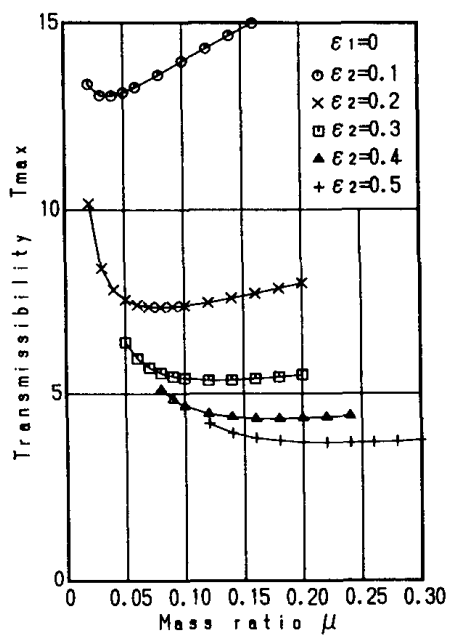

図 $11 T_{\max }$ と $\mu$ との関係

振効果が大きい。この計算結果を用いて高いほうの山 の高さ $T_{\max }$ と $\mu$ との関係を示したのが図 11 である. 図 11 から動吸振器には損失係教の大きなゴムを用い るのがよいことがわかる.そして各 $\varepsilon_{2}$ ごとに最適の $\mu$ が存在することがわかる．実用上防振ゴムの損失係数 $\varepsilon_{2}$ は 0.5 以下と考えられるので動吸振器の最適な質 


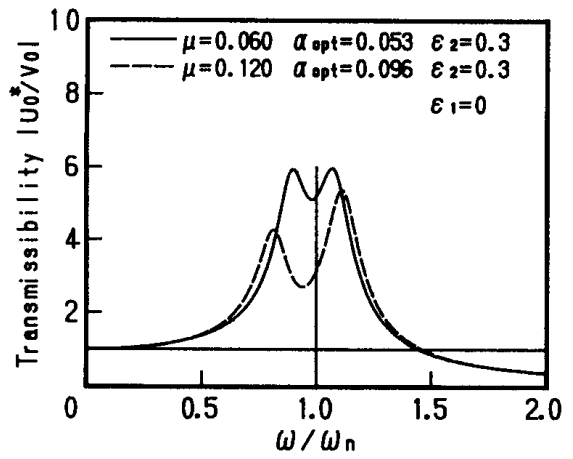

図 12 最適質量比を用いた振動伝達率線図

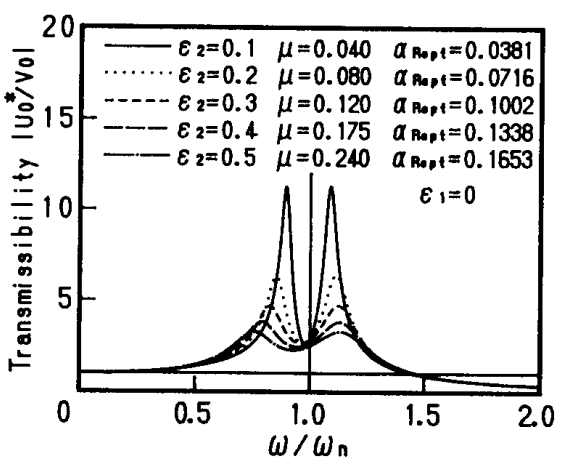

図 13 補正係数により山の高さを一致させた振動伝達率 線図

量比 $\mu$ は 0.3 を超えることはないであろう.図 12 は $\varepsilon_{1}=0, \varepsilon_{2}=0.3$ の場合の計算例である. 図 11 から最良 の $\mu$ は 0.12 となるから式(8)の $\alpha$ を用いて振動伝達

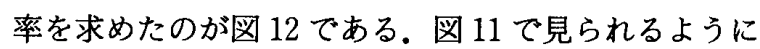
最大振動伝達率 $T_{\max }$ の值は極小点付近で極めてゆる やかに変化しているから $\mu$ の值を半分にした場合も 図 12 に記入してある. $T_{\max }$ の值は $\mu=0.12$ の場合の ほうが確かに低くはなっているが $\mu=0.06$ の場合と比 べて著しい改善はなっていない. 動吸振器はなるべく 小さいものが望ましいという実用上の観点からすれば $\mu=0.06$ から 0.07 を採用するのが実際的であろう.図 12 は $\mu=0.12$ の曲線は左右の山の高さが等しくない が，これは $\alpha$ として式（8)を用いたためである。式 (14)の形にして適当な $R$ を選べば図 13 のようにな る.

調節可能な減衰器を用いる場合は最適同調条件と最 適損失係数を用いることにより，俉は大ければ大き いほど $T_{\max }$ は小さくなる。しかし防振ゴムの場合は 損失係数が与えられているため $\mu$ を大きくして大き な動吸振器を採用することによる性能向上と損失係数 が最適值から離れることによる性能劣化とが重なって ある $\mu$ の值で性能は最良になる。この

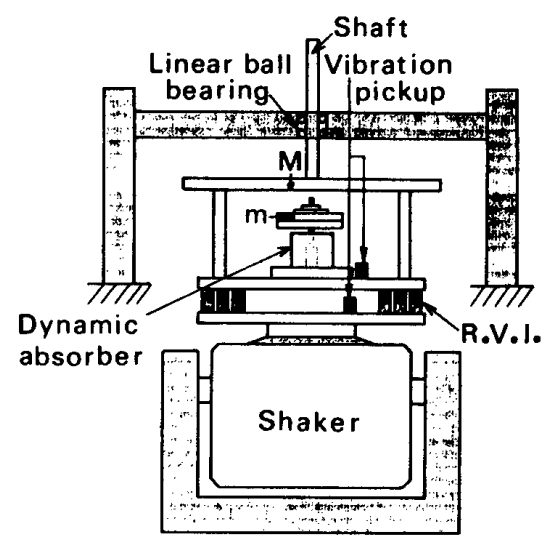

図 14 実験装置の略図

失係数に対応する $\mu$ の值よりいくらか大きい值であ る. 図 12 の数值例では $\mu=0.06$ に対する最適損失係数 が $\varepsilon_{2}=0.3$ になっているので最良の $\mu$ はこの約 2 倍で ある。

\section{5. 振動伝達率測定実験}

図 14 に示すように動電形加振機上の基礎鋼板に数 個の防振ゴム (R. V.I.)を並列に設置しその上に主系 の質量 $M$ をのせる．そしてこれに二次系の質量 $m$ を もつ動吸振器が取付けられている，振動伝達率を測定 するために振動変位測定用の加速度ピックアップを 2 個用いた。主系の積載質量 $M$ はリニアボールベアリ ングと専用シャフトを使用しているために横振れが少 なく，また摩擦が少ないので軸方向のみ振動する安定 した正弦波形が得られるよう工夫した構造である。動 吸振器内の防振ゴムに積載した質量 $m$ についても同 様な構造になっており安定した振動波形が得られてい る.動吸振器に用いた防振ゴムは損失係数の大きな ME-12-IIR 20(ゴム材質：ブチルゴム) を使用した。

実験方法は動電形加振機を変位複振幅 $0.2 \mathrm{~mm}$, $10 \sim 50 \mathrm{~Hz}$ の周波数範囲で加振し, 上下の振動ピック アップからの出力波形をディジタルオシロスコープ画 面で観測し，上下の振動波形の振幅比より振動伝達率 值を算出した。

\section{6. 実 験 結 果}

主系と動吸振器には同じ防振ゴム $\mathrm{ME}-12-\mathrm{IIR} 20$ を 用いた. 主系の全質量 $M=10.8 \mathrm{~kg}$, 動吸振器の質量 $m$ $=1.09 \mathrm{~kg}$ であるため,ばね定数比が $\alpha_{\mathrm{opt}}$ に近い值を とるよう動吸振器には防振ゴム 1 個, 主系には 12 個 並列に設置した，用いた防振ゴム（直径 $12 \mathrm{~mm}$, 厚さ $12 \mathrm{~mm}$ )のばね定数 $k_{1}^{\prime}, k_{2}^{\prime}$ と損失係数 $\varepsilon_{1}, \varepsilon_{2}$ とを次の 方法により算出する.式(5)，（6）において $\mu=0$ とお 


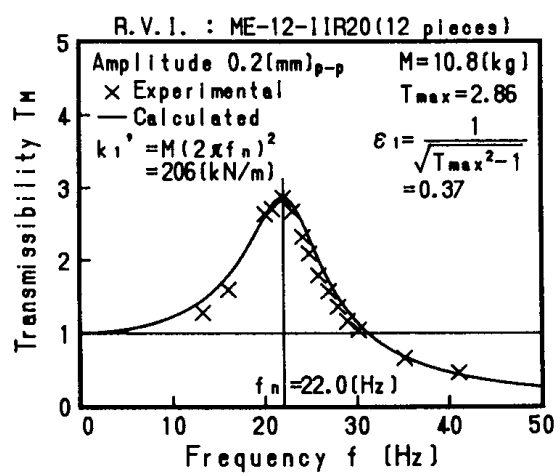

図 15 共振曲線より $k_{1}^{\prime} と \varepsilon_{1}$ の算出

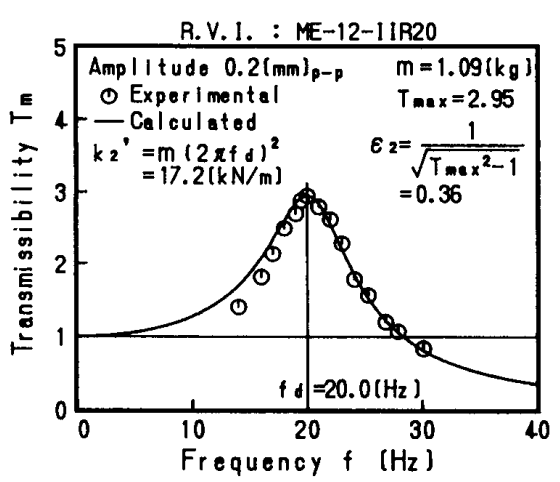

図 16 共振曲線より $k_{2}^{\prime} と \varepsilon_{2}$ の算出

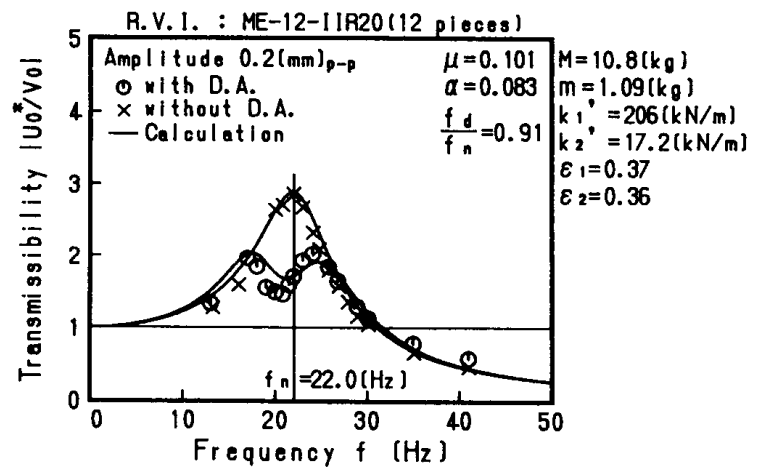

図 17 計算と実験を比較した動吸振系の制振効果

けば主系のみの振動伝達率が求められ, 単純な複素ば ねモデルの防振系を表している.そこで, 最大振動伝 達率 $T_{\max }$ と固有角振動数 $\omega_{n}$ が実験より求められる ならば次式から防振ゴムの動的ばね定数と損失係数が 計算できる。

$$
\begin{aligned}
& k_{1}^{\prime}=M \cdot \omega_{n}^{2} \cdots \cdots \cdots \\
& \varepsilon_{1}=1 / \sqrt{T_{\max }^{2}-1}
\end{aligned}
$$

図 15 は防振ゴムを基礎鋼板に 12 個並列に設置した主 系の防振系の共振曲線より $k_{1}^{\prime}$ と $\varepsilon_{1}$ を求めたグラフで ある.ゴム材質がブチルゴムであるので損失係数 $\varepsilon_{1}=$ 0.37 とかなり大きな值が得られている．動吸振器に用 いた同防振ゴム 1 個のときの $k_{2}^{\prime}$ と $\varepsilon_{2}$ の值を図 16 に

\begin{tabular}{|c|c|c|c|c|c|c|}
\hline \multirow{2}{*}{$\alpha$} & \multirow[t]{2}{*}{$\mu$} & \multicolumn{3}{|c|}{ Mass ratio } & \multicolumn{2}{|c|}{$\mathrm{m} / \mathrm{M}$} \\
\hline & & 0.07 & 0.08 & 0.09 & 0.10 & 0.12 \\
\hline \multirow[b]{2}{*}{$k_{2}{ }^{\prime}$} & 0.05 & & $\overline{0.76}$ & $0 . \overline{71}$ & $\begin{array}{l}0.65 \\
0.75\end{array}$ & \\
\hline & 0.06 & & 0.58 & 0.65 & & \\
\hline \multirow[t]{2}{*}{$k_{1}^{\prime}$} & 0.07 & & & & $\begin{array}{l}0.53 \\
0.50\end{array}$ & $\begin{array}{l}0.51 \\
0.46\end{array}$ \\
\hline & 0.08 & $\begin{array}{l}0.51 \\
0.46\end{array}$ & $\begin{array}{l}0.47 \\
0.40\end{array}$ & $\begin{array}{l}0.47 \\
0.45\end{array}$ & & \\
\hline
\end{tabular}

表 1 動吸振器を取付けたときの制振効果

R.V.1. : $M E-12(4$ pleces $)$

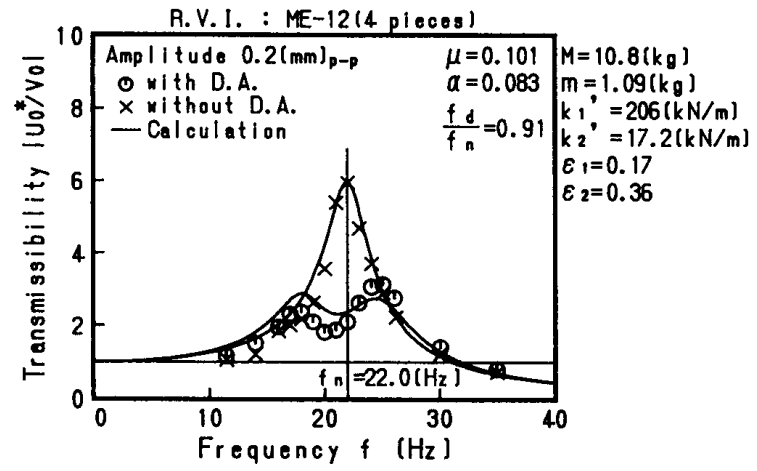

図 18 計算と実験を比較した動吸振器の制振効果

示す. $\varepsilon_{2}$ の值が主系とわずかに異なるがこの值を採用 する.図 14 に示す防振系の振動伝達率を求めたものが 図 17 である. 図 17 はほほ最適值をもった動吸振器に なっているので, 動吸振器がないときのおよそ $40 \% く$ らい制振されている.図 17 中の曲線は計算曲線で実験 值とかなりよく一致している.図 18 は 4 個の防振ゴム ME-12(ゴム材質：天然ゴム)を基礎鋼板に設置した 主系に前述の動吸振器を取付けた振動伝達率線図であ る.この防振ゴムは ME-12-IIR 20 と形状がまったく 同じで材質のみが異なるものであり， $k_{1}^{\prime}=206 \mathrm{kN} / \mathrm{m}$ の值は実験より算出されたものである.この防振系も 最適值とほほ等しいためにおよそ $50 \%$ 程度の制振が なされていることがわかる，このグラフでも，実験值 と計算曲線の傾向はよい一致を示している.

表 1 は主系の積載質量 $M=10.8 \mathrm{~kg}$ を一定状態にし 質量比 $\mu$ とばね定数比 $\alpha$ とを変化させて実験を行っ た結果の制振効果を百分率で表したものである．表 1 中の数字の上段は防振ゴム ME-12を示し, 下段は KA-12 の防振ゴムである. 動吸振器内の防振ゴムは ME-12-IIR 20 を使用している. $\mu$ と $\alpha$ とに最適值が ありこの状態で動吸振器を設置することにより, 最大 振動伝達率のおよそ $60 \%$ 程度を吸収できることがわ かった。 
7. 結

曹

防振ゴムと積載質量とよりなる 1 自由度防振系の共 振周波数近傍の振動伝達率を下げるために，防振ゴム を用いた動吸振器を設置した 2 自由度振動系の振動解 析と振動层達率測定実験を実施し制振効果について検 討した。 その結果以下のことが明らかになった。

（1）主系に減衰がない場合，定点理論を適用して 最適同調条件，最適損失係数を導くことができる。こ れらは質量比のみできまる。

（2）主系に減衰がある場合の制振効果領域内の動 吸振器の最適調整には無隇衰時の最適同調条件に補正 係数を乗じたものと最適損失係数 (最適隇衰比)を用い ればよい。

（3）防振ゴムを用いた動吸振器の解析結果で導出 した最適調整に必要な最適同調条件および最適損束係
数はばね-減哀器系のそれらと等価である.

（4）防振ゴムを複素ば秝モデルで近似した計算曲 線は実験値と比較の結果よい一致を示した。

以上のことから，本解析手法で防振ゴムを用いた動 吸振器の実用的な最適制振設計を行うことができる。

最後に, 最適な動吸振器を設計するために防振ゴム (ME-12-IIR 20)をご提供いただいた昭和電線電䌫株 式会社に感謝申し上げる.

\section{文献}

(1) Den Hartog, J.P., Mechanical Vibrations, 4th ed., (1956), 87, McGraw-Hill.

（2）日本機械学会，機械システムのダイナミックス入門, (1990), 238-244.

（3）尾崎 - 橋本 - 神保, 機構論, No. 930-63 (1993-10), 503.

（4）尾崎 - 橋本 - 神保, 機構論, No. 930-63 (1993-10), 508.

（5）尾崎 - 橋本 - 神保, 機粠論, No. 940-64 (1994-3), 599. 